\title{
PREDICTION OF HOTEL BOOKING CANCELLATION USING DEEP NEURAL NETWORK AND LOGISTIC REGRESSION ALGORITHM
}

\author{
Nugroho Adi Putro'*); Rendi Septian²; Widiastuti³; Mawadatul Maulidah4; \\ Hilman Ferdinandus Pardede ${ }^{5}$ \\ Computer Science Study Program 1, 2,3,4,5 \\ STMIK Nusa Mandiri \\ www.nusamandiri.ac.id \\ 14002328@nusamandiri.ac.id 1*; 14002348@nusamandiri.ac.id 2; widiastuti.wtu@nusamandiri.ac.id 3; \\ 14002373@nusamandiri.ac.id ${ }^{4}$; hilman@nusamandiri.ac.id 5
}

\section{$\left.{ }^{*}\right)$ Corresponding Author}

\begin{abstract}
Booking cancellation is a key aspect of hotel revenue management as it affects the room reservation system. Booking cancellation has a significant effect on revenue which essentially affects request the board choices in the inn business. To reduce the cancellation effect, the hotel applies the cancellation model as the key to addressing this problem with the machine learning-based system developed. This study, using data collected from the Kaggle website with the name hotel-bookingdemand dataset. The research objective was to see the performance of the deep neural network method which has two classification classes, namely cancel and not. Then optimized with optimizers and learning rate. And to see which attribute has the most role in determining the level of accuracy using the Logistic Regression algorithm. The results obtained are the Encoder-Decoder Layer by adamax optimizer which is higher than that of the DecoderEncoder by adadelta optimizer. After adding the learning rate, the adamax accuracy for the encoders and encoders decreased for a learning rate of 0.001 . The results of the top three ranks of each neural network after adding the learning rate show that the smaller the learning rate, the higher the accuracy, but we don't know what the optimal value for the learning rate is. By using the Logistic Regression algorithm by eliminating several attributes, the most influential level of accuracy is the state attribute and total_of_special_requests, where accuracy increases when the state attribute is removed because there are 177 variations in these attributes.
\end{abstract}

Keywords-Bookings Cancellation; Deep Neural Network; Logistic Regression;

Abstrak-Pembatalan pemesanan merupakan aspek kunci dari manajemen pendapatan hotel karena mempengaruhi sistem reservasi kamar. Pembatalan pemesanan berpengaruh signifikan terhadap pendapatan yang berdampak signifikan terhadap keputusan manajemen permintaan di industri hotel. Untuk mengurangi efek pembatalan, hotel menerapkan model pembatalan sebagai kunci untuk mengatasi masalah ini dengan sistem berbasis pembelajaran mesin yang dikembangkan. Dalam penelitian ini menggunakan pengumpulan data dari website Kaggle dengan nama dataset hotel-booking-demand. Tujuan penelitian adalah untuk melihat performansi metode deep neural network yang memiliki dua kelas klasifikasi yaitu cancel dan not. Kemudian dioptimalkan dengan pengoptimal dan kecepatan pembelajaran. Dan untuk melihat atribut mana yang paling berperan dalam menentukan tingkat akurasi menggunakan algoritma Regresi Logistik. Hasil yang diperoleh adalah Encoder-Decoder Layer oleh adamax optimizer lebih tinggi dari pada Decoder-Encoder oleh adadelta optimizer. Setelah menambahkan kecepatan pembelajaran, akurasi adamax untuk pembuat enkode dan pembuat enkode menurun untuk kecepatan pembelajaran 0,001. Hasil dari tiga peringkat teratas dari setiap jaringan neural setelah menambahkan kecepatan pemelajaran menunjukkan bahwa semakin kecil kecepatan pemelajaran, semakin tinggi keakuratannya, tetapi kami tidak tahu berapa nilai optimal untuk kecepatan pemelajaran tersebut. Dengan menggunakan algoritma Regresi Logistik dengan menghilangkan beberapa atribut maka tingkat akurasi yang paling berpengaruh adalah atribut state dan total_of_special_requests, dimana akurasi meningkat ketika atribut state dihilangkan karena terdapat 177 variasi pada atribut tersebut.

Kata Kunci: Pembatalan Pemesanan; Jaringan Saraf Dalam; Regresi Logistik.

\section{INTRODUCTION}

Tourism is one of the most expanded industries in the world and its importance in the global economy does not raise any doubts(SánchezMedina \& C-Sánchez, 2020). Evidence of its growth can be seen when considering that in 1995 the 
number of international tourists slightly exceeded the 500 million mark, whereas in 2018 this number increased to 1400 million. In 2018 alone the number of international tourists grew by $5 \%$. At the same time, export earnings generated by tourism have grown to USD 1.7 trillion (World Travel Organization, 2019). This makes the area a genuinely worldwide power for monetary development and advancement, driving the production of more and better positions and filling in as an impetus for advancement and business. To put it plainly, the travel industry is assisting work with bettering lives for a huge number of people and changing entire networks (World Travel Organization, 2019).

Booking abrogations fundamentally affect the request the board choices in the accommodation business (Antonio, De Almeida, \& Nunes, 2017). To mitigate the effect of cancellations, hotels implement rigid cancellation policies and overbooking tactics, which in turn can hurt revenue and the hotel reputation. (Antonio, De Almeida, et al., 2017). Deep learning has become one of the highly recommended machines learning approaches for handling many of the natural language processing (NLP) research challenges such as named-entity recognition, machine translation, and sentiment analysis (Al-Smadi, Talafha, Al-Ayyoub, \& Jararweh, 2018).

The main objective of this research is to see the performance of the deep neural network method which has two classification classes, namely canceled and not. Then optimized with an optimizer and learning rate. And also to see which attribute has the most role in determining the level of accuracy using the Logistic Regression algorithm.

Cancellations are a key aspect of hotel revenue management as they impact the room reservation system. Very little is known about the reasons why customers cancel, or how it can be avoided (Sánchez-Medina \& C-Sánchez, 2020).

Research that has been done before in terms of Prediction of Hotel Booking Cancellations such as research conducted by Agustín J. Sánchez-Medina and Eleazar C-Sánchez (Sánchez-Medina \& CSánchez, 2020) with the title Using machine learning and big data for efficient forecasting of hotel booking cancellations. The purpose of this paper is to propose a way to predict the cancellation of hotel reservations using only 13 independent variables, in addition to the variables most frequently asked by customers when they make a reservation. Machine learning techniques, which include neural networks optimized by the applied genetic algorithm, achieve cancellation rates of up to $98 \%$. The methodology proposed is not only for finding out about cancellation rates but also for identifying customers who are most likely to cancel.
Further related research, namely research conducted by Antonio et al entitled Prediction of Hotel Booking Cancellation with Machine Learning Classification Model (Antonio, De Almeida, et al., 2017). This paper demonstrates the importance of separating data sets and feature engineering in machine learning models. It also emphasizes the need for machine learning researchers/ practitioners to have multiple domain knowledge. Another important aspect is the technological aspect of the development of this prototype. Open source, Hadoop/Spark group, running R Server, permitting handling to be dispersed across various bunch machines, exploiting the accessible figuring power and amazing AI strategies for the XGboost tree, showing how machine learning systems can run automatically, aggregating data new every day, along with previous prediction errors and clicks to improve itself continuously. The test results gave good results for both hotels, with an accuracy of above 0.84 . However, the expected arrival accuracy is 0.736 for $\mathrm{H} 1$, and 0.712 for $\mathrm{H} 2$. This shows that there is still room for improvement.

Further related research by (Antonio, De Almeida, \& Nunes, 2019). This examination expects to make a model to foresee the chance of booking abrogation carried out in a choice emotionally supportive network and its effect on request the board choices, by building and utilizing a model in two lodgings. The model, in light of a mechanized AI framework intended for nonstop learning, made two commitments. to start with, advancement of preparing strategies and weighting systems intended to catch changes in scratch-off designs after some time and gain from the earlier day's hit and blunder forecasts. Second, the formation of another action - Minimum Frequency - to quantify the precision of forecasts after some time. This model showed its viability, with results surpassing 84\% mistake, $82 \%$ exactness, and $88 \%$ in Area Under the Curve (AUC). The framework permits inns to anticipate net interest and settle on better choices about which appointments to acknowledge and dismiss, what costs to make, and the number of more rooms to sell. With the examination has done having the option to methodically foresee appointments with a high likelihood of abrogation permits inns to lessen scratch-offs by 37 rate focus to stay away from retraction of lodging demands.

The next related research is (Antonio, Almeida, \& Nunes, 2017). the research conducted had the same problem as the journal (Antonio, De Almeida, et al., 2017)(Antonio, De Almeida, et al., 2019). However, using the data set of four resort hotels and addressing the prediction of booking cancellation as a classification problem within the scope of data science, the results show that it is 
possible to build a model to predict booking cancellations with an accuracy of more than 90\%.

Research conducted by Jian Wang and Amar Duggasani (Wang \& Duggasani, 2020) entitled Anticipating dwelling reservations with long transient memory-based irregular neural associations overviews three sorts of deciding procedures typically used for all intents and purposes and immediately portrays the possibility of neural associations. This assessment furthermore proposes two transient memory (LSTM) models reliant on dreary neural associations. The data used and attempted is the booking data from USA lodgings using six AI (ML) models from the decision tree, multi-layer perceptron, rope, direct backslide, sporadic boondocks, and edge was moreover evaluated and attempted against the identical dataset. The outcomes utilizing the LSTM model have expanded by about $3.0 \%$ contrasted with utilizing the best Machine Learning model.

Further related research, namely Cancellation Predictor for Revenue Management applied in the hospitality industry by R. van Leeuwen(Leeuwen, 2018). The research conducted aims to create a model that can be implemented not only in the hotel industry but also in the airline industry or the car rental industry for example. with the Passenger Name Record, (PNR) approach as a classification model applied to a dataset of international hotel companies, to increase revenue. This paper describes the steps from raw data to implementation by applying four models, namely Naive Bayes, logistic regression, decision tree, and random forest. In terms of accuracy, precision, and F score, random forest performed best. Refundable features $(\mathrm{y} / \mathrm{n})$, lead time, channels are important ones, according to the different models.

Research conducted by (Urraca, SanzGarcia, Fernandez-Ceniceros, Sodupe-Ortega, \& Martinez-de-Pison, 2015) presents a crossover technique, where the KDD plot is advanced to fabricate an exact closefisted model. The philosophy attempts to track down the best model by utilizing hereditary calculations to upgrade the KDD plot which is framed by the phases of choosing highlights, changing slanted information and yield information, setting boundaries, and picking a confounded model. This investigation shows that the streamlining of these means essentially improves the generalizability of the model in a few UCI data sets. The strategy applied to demonstrate room request saving uses the booking information base of an inn situated in the district of Northern Spain and the aftereffects of the proposed technique help make a model with a higher speculation limit and lower intricacy than that got with the exemplary KDD measure.
Research conducted by Eid Alotaibi(ALOTAIBI, 2020) Application of Machine Learning in the Hospitality Industry: A Critical Review to provide insight into the role of machine learning and integrated technology in the hospitality industry. in the study, it was found that machine learning helps in demand forecasting, price forecasting, order cancellation prediction, financial efficiency, and work efficiency. Machine learning algorithms outperform predictive accuracy over statistical models.

In this study A Machine Learning Approach To Improving Forecasting Accuracy Of Hotel Demand: A Comparative Analysis Of Neural Networks And Traditional Models (Lee, 2020) suggests a combined neural network method that combines heterogeneous data sets - time series and pre-order information along with seasonal components. This study provides a comparative analysis to increase the accuracy of forecasting by investigating various forecasting methods including pre-order models, time series models. The Ourexhaustive study shows the neural network approach outperforms the traditional estimation model as a whole. Also, the actual behavior of daily requests is a more complex phenomenon than can be captured by single data types, and in this study, the combined neural network model can improve the accuracy of estimates.

The latest related research from (Afrianto \& Wasesa, 2020). This investigation intends to build up a forecast model to decide the chance of requesting convenience postings utilizing the Airbnb dataset by creating AI models, specifically Logistics Regression, Decision Tree, K-Nearest Neighbor (KNN), and Random Forest. This paper reviewing the model using the AUC-ROC score and the model improvement time utilizing a ten times three-way division and ten times cross-approval methods. The subsequent normal AUC-ROC score, the Random Forest Classifier outflanked different models assessed. The three-way split method had an AUC-ROC score $15.03 \%$ higher than the Choice Tree, $2.93 \%$ higher than the KNN, and $2.38 \%$ higher than the Logistic Regression. In the crossendorsement system, it has a $26.99 \%$ higher AUCROC score than the Decision Tree, $4.41 \%$ higher than the KNN, and 3.31\% higher than the Logistic Regression. The Decision Tree Model has the most insignificant AUC-ROC score yet has the tiniest model improvement time. The exhibition of the irregular woods model in anticipating the probability of booking convenience records was predominant. This model can be utilized by shared convenience proprietors to improve their income the board reaction. This study analyzed to see the performance of the deep neural network method. Then optimized with optimizers and learning rates. 
And to see which attribute has the most role in determining the level of accuracy using the Logistic Regression algorithm. To the authors' knowledge, no previous researcher has specifically conducted a similar study in the hotel industry.

\section{MATERIALS AND METHOD}

The research framework proposed for this research draws a dataset from (Antonio, de Almeida, \& Nunes, 2019), which in this research uses the DNN algorithm and Logistic Regression. The data was downloaded and cleaned by Thomas Mock and Antoine Bichat and has been upload at https://www.kaggle.com/jessemostipak/hotelbooking-demand. In this research, we using python for running DNN and Logistic Regression.

\section{Data}

This informational collection contains booking data for a city inn and a retreat inn and incorporates data, for example, when the booking was made, length of stay, the number of grown-ups, youngsters, or potentially indulges, and the number of accessible parking spots, in addition to other things.. The dataset consists of 119,390 instances with 32 attributes. With the target label of the is_canceled attribute. To develop and evaluate the model, these data are further assigned into development ( $80 \%$ booking data for training sets) and testing datasets (20\% of booking data)

\section{Data Preprocessing}

The preprocessing stage is the stage that is carried out before the classification process on the dataset. The data preprocessing process is as follows

\section{Update and Drop Null Attribute}

In this dataset, several columns have null values, but some have a large percentage of null values. Therefore, for attributes that have a large percentage, the attribute will be removed, while for a small percentage, then update the zero value. Table 1 is the result value of the null value attribute

Table 1. Data Null Values

\begin{tabular}{cccc} 
Attribute & $\begin{array}{c}\text { Count } \\
\text { Null }\end{array}$ & Percentage & Action \\
\hline children & 4 & $0,003 \%$ & $\begin{array}{c}\text { Update zero } \\
\text { value }\end{array}$ \\
\hline country & 488 & $0,04 \%$ & $\begin{array}{c}\text { Update zero } \\
\text { value }\end{array}$ \\
\hline agent & 16.340 & $13,68 \%$ & $\begin{array}{c}\text { Update zero } \\
\text { value }\end{array}$ \\
\hline company & 112.593 & $94,30 \%$ & Drop Attribute \\
\hline
\end{tabular}

Source: (Adi Putro, et al, 2021)

\section{Removes lots of unique variations attribute}

Removes the reservation_status_date attribute because it has 926 unique variations. It causes the result performance of the classification process to decrease.

\section{Update to numeric Value}

Converts column values to numeric values for the following attributes

- Attribute Hotel change to 0 for Resort Hotel and 1 for City Hotel

- Attribute arrival_date_month change value 1 to 12 following the month value

- Attribute country to cat codes which consists of 177 countries

- Attribute meal, distribution_channel, assigned_room_type, market_segment, reserved_room_type, customer_type, deposit_type change the data object into a dummy / indicator variable

Removing the reservation_status column, because reservation_status includes the 'Canceled' feature because this feature can predict the cancellation directly with $100 \%$ accuracy

\section{Deep Neural Network}

A Deep Neural Network (DNN) is an artificial neural network that has many layers. In general, deep neural networks have more than 3 layers (input layer, $\mathrm{N}$ hidden layers, output layer), in other words, Multilayer perceptron with more layers. Because there are relatively many layers, it is called deep. The learning process at DNN is known as deep learning (Putra, 2019).

Deep neural networks can re-use the features computed in a given hidden layer in higher hidden layers (Kriegeskorte \& Golan, 2019). This enables a deep neural network to exploit compositional structure in a function and to approximate many natural functions with fewer weights and units (Kriegeskorte \& Golan, 2019). Deep neural network models have become a powerful tool of machine learning and artificial intelligence. Figure 1. is the architecture of a Deep Neural Network:

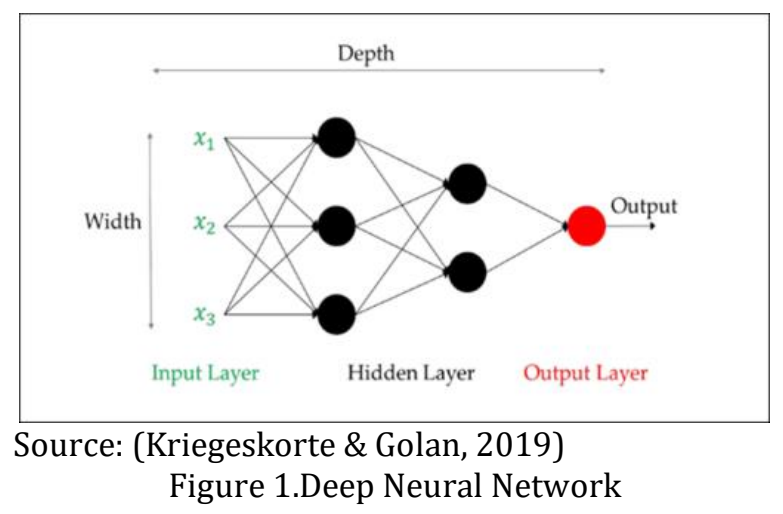


The architecture of our DNN used is composed of three fully connected hidden layers (Dense) and activation function ReLu for input and hidden layers and Sigmoid for the output layer. The input layer is equal to the dimension of input data. The number of neurons per hidden layer is using encoder-decoder and decoder-encoder neural network architecture. During the training process, the parameters of the DNN manually add Optimizer and Learning Rate. For each batch of training data, parameters of the DNN are modified gradually.

\section{Layers}

The encoder accepts an input which reduces to a smaller number of outputs or decreases the input to a smaller number of bits. Meanwhile, the decoder receives input from the encoder and tries to restore it to its original size. The encoders used in this experiment are

- Encoder-Decoder hidden layers $512 \quad\left(1^{\text {st }}\right)$, 256(2 $\left.2^{\text {nd }}\right), 512\left(3^{\text {rd }}\right)$

- Decoder-Encoderhiden layers $256 \quad\left(1^{\text {st }}\right)$, $512\left(2^{\text {nd }}\right), 256\left(3^{\text {rd }}\right)$

\section{Optimizer}

An optimizer is an algorithm or method used to change neural network attributes such as weight and learning rate to reduce losses. The optimizer used in this research is derived from the Keras model including

- SGD

Gradient descent optimizer.

The update rule for parameter $\mathrm{w}$ with gradient $\mathrm{g}$ when momentum is 0 :

$w=w-$ learning rate $* g$

Update rule when momentum is larger than $0: 3$

velocity $=$ momentum $*$ velocity - learning rate $*$ g

When nesterov $=$ True, this rule becomes:

velocity $=$ momentum $*$ velocity - learning rate $*$

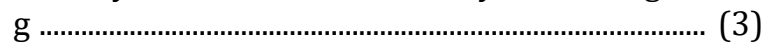

$w=w+$ momentum $*$ velocity - learning rate $*$ $g$

\section{- $\quad$ RMSprop}

RMSprop is to: Maintain a moving (limited) normal of the square of inclinations. Separation the angle by the foundation of this normal. This execution of RMSprop utilizes plain energy, not Nesterov force. The focused form furthermore keeps a moving normal of the slopes and uses that normal to assess the difference.
- Adam

Adam enhancement is a stochastic angle plummet strategy that depends on a versatile assessment of first-request and second-request minutes. According to (Kingma \& Ba, 2015), the method is "computationally efficient, has little memory requirement, invariant to diagonal rescaling of gradients, and is well suited for problems that are large in terms of data/parameters".

\section{- Adadelta}

Adadelta improvement is a stochastic slope plummet strategy that depends on versatile learning rate per measurement to address two disadvantages, The nonstop rot of learning rates all through preparing and the requirement for a physically chosen worldwide learning rate. Adadelta is a more vigorous expansion of Adagrad that adjusts learning rates dependent on a moving window of angle refreshes, rather than aggregating every single past inclination. Along these lines, Adadelta keeps learning in any event, when numerous updates have been finished.

- Adagrad

Adagrad is an enhancer with boundary explicit learning rates, which are adjusted comparative with how regularly a boundary gets refreshed during preparation. The more updates a boundary gets, the more modest the updates.

\section{- Adamax}

It is a variation of Adam dependent on the endlessness standard. Default boundaries follow those given in the paper. Adamax is some of the time better than adam, particularly in models with embeddings.

- Nadam

Similar to Adam is RMSprop with force, Nadam is Adam with Nesterov energy.

- Ftrl.

These include improvements in the context of traditional supervised learning based on an FTRLProximal online learning algorithm (which has excellent sparsity and convergence properties) and the use of per-coordinate learning rates.

\section{Learning Rate}

Learning rate is one of the training parameters to calculate the weight correction value during the training process. The range of constant / alpha values is in the range zero (0) to one (1). In this experiment, the learning rate used is $0.1 ; 0.01$; $0.005 ; 0.001$.

\section{Logistic Regression}

Logistic Regression is used to describe and test the hypotheses (Peng, Lee, \& Ingersoll, 2002). Choosing the right variables and avoiding the highly correlated variables must be observed when using 
Logistic Regression (Aggarwal \& Ranganathan, 2017). The indicator factors in Logistic Regression can be absolute or mathematical, and the objective variable of Logistic Regression is twofold or dichotomous. In this manner, Logistic Regression can't anticipate target factors of multiple classes. Albeit Logistic Regression may have a few shortcomings, it can frequently contend with other AI procedures, like neural organizations, support vector machine, irregular woodland, and slope boosting (Antonio, Almeida, et al., 2017). The formalization of logistic regression is stated as follows (Peng et al., 2002):

$\pi=$ Probability $(Y=$ outcome of interest $\mid X=$

$x$, a specific value of $X$ )

$\pi=\frac{e^{\alpha+\beta_{1} x_{1}+\beta_{2} x_{2}+\cdots+\beta_{n} x_{n}}}{1+e^{\alpha+\beta_{1} x_{1}+\beta_{2} x_{2}+\cdots+\beta_{n} x_{n}}}$

where:

$\pi$ is the probability of the outcome of interest

e is 2.71828 (the base of the system of natural logarithms

$\alpha$ is Y-intercept

$\beta_{\mathrm{n}}$ is the regression coefficients

$\mathrm{X}_{\mathrm{n}}$ is a set of predictor variables

As far as strategy, Logistics Regression is generally simple to utilize and needn't bother with any hyper-boundary advancement arrangement. The model can likewise contend with more refined AI models. In any case, this examination researches the use of solitary models because of their straightforwardness and execution ease. Particular models can in any case beat gathering models (Antonio, Almeida, et al., 2017)

Another machine learning model to find the relationship between the features (input) discrete/continuous with the probability of a certain discrete output is used Logistic Regression.

We are also looking for the Most Contributing Features using this algorithm. Where later all features will be removed one by one.

\section{RESULT AND DISCUSSIONS}

The total input layer used was 59. At the preprocessing stage, there was an increase in the number of attributes because there were attributes that were changed to dummy attributes of the preprocessing process. In testing using the Deep Neural Network method with Encoder-Decoder and Decoder-Encoder architectures and 8 Optimizer, the accuracy results of the two neural network architectures can be seen in the following table 2 and table 3 .
Table 2. Result DNN Encoder-Decoder

\begin{tabular}{cc}
\hline Optimizer & Accuracy \\
\hline Adamax & $\mathbf{8 6 , 5 7 \%}$ \\
Adadelta & $86,52 \%$ \\
Nadam & $86,45 \%$ \\
Adagrad & $86,45 \%$ \\
Adam & $86,34 \%$ \\
RMSProp & $85,31 \%$ \\
SGD & $83,33 \%$ \\
Ftrl & $62,54 \%$ \\
\hline
\end{tabular}

Source: (Adi Putro, et al, 2021)

Table 3. Result DNN Decoder-Encoder

\begin{tabular}{cc}
\hline Optimizer & Accuracy \\
\hline Adadelta & $\mathbf{8 6 , 5 6 \%}$ \\
Adagrad & $86,48 \%$ \\
Adamax & $86,43 \%$ \\
Adam & $86,25 \%$ \\
RMSprop & $85,34 \%$ \\
SGD & $82,58 \%$ \\
Nadam & $86,31 \%$ \\
Ftrl & $62,54 \%$
\end{tabular}

Source: (Adi Putro, et al, 2021)

From these results, the top 3 rankings on EncoderDecoder architecture with optimizer Adamax are $86,57 \%$, Adadelta86,52\%, Nadam86,45\%. Then followed by Adagrad86,45\%, Adam86,34\%, RMSProp85,31\%, SGD83,33\%, Ftrl62,54\%.

For Decoder-Encoder architecture top 3 rangking are Adadelta86,56\%, Adagrad86,48\%, Adamax86,43\%. Then followed by Adam86,25\%, RMSprop85,34\%, SGD82,58\%, Nadam86,31\%, Ftrl62,54\%.

After getting the top 3 rankings from 2 architecture neural network, then we used learning rate 0.1 ; $0.01 ; 0.005 ; 0.001$ for 3 top rankings optimizer, the results can be seen in table 4 and table 5 :

Table 4. Result learning Rate Encoder-Decoder

\begin{tabular}{ccc}
\hline Optimizer & $\begin{array}{c}\text { Learning } \\
\text { Rate }\end{array}$ & Accuracy \\
\hline & 0,1 & $84,59 \%$ \\
Adamax & 0,01 & $85,40 \%$ \\
& 0,005 & $85,66 \%$ \\
& 0,001 & $85,58 \%$ \\
\hline Adadelta & 0,1 & $85,62 \%$ \\
& 0,01 & $85,66 \%$ \\
& 0,005 & $85,71 \%$ \\
Nadam & $\mathbf{0 , 0 0 1}$ & $\mathbf{8 5 , 7 3 \%}$ \\
\hline & 0,1 & $74,99 \%$ \\
& 0,01 & $83,20 \%$ \\
& 0,005 & $83,67 \%$ \\
\hline
\end{tabular}

Source: (Adi Putro, et al, 2021) 
Table 5. Result learning Rate Decoder-encoder

\begin{tabular}{ccc}
\hline Optimizer & $\begin{array}{c}\text { Learning } \\
\text { Rate }\end{array}$ & Accuracy \\
\hline & 0,1 & $85,68 \%$ \\
Adadelta & 0,01 & $85,66 \%$ \\
& 0,005 & $85,65 \%$ \\
& 0,001 & $85,67 \%$ \\
\hline Adagrad & 0,1 & $85,64 \%$ \\
& 0,01 & $85,68 \%$ \\
& 0,005 & $85,70 \%$ \\
Adamax & 0,001 & $85,69 \%$ \\
\hline & 0,1 & $85,33 \%$ \\
& 0,01 & $85,80 \%$ \\
& 0,005 & $85,78 \%$ \\
\hline
\end{tabular}

Source: (Adi Putro, et al, 2021)

From the results of the table above we can see that for the encoders, the highest aldadelta optimizer results are obtained with a learning rate of 0.001 , which is $85,73 \%$, while for the adamax decoderencoder architecture it gets an accuracy of $85,91 \%$ with a learning rate of 0.001 .

Then with the Logistic Regression Algorithm using the same testing and training data, the result is $79.66 \%$. From these results, we will then look for which attribute has the most role in determining the level of accuracy, which later we will remove each attribute one by one.

Here are the results of the most role features of the logistic regression algorithm in table 6.

Table 6. Result in most role features

\begin{tabular}{cc}
\hline Attribute & Accuracy \\
\hline country & $\mathbf{8 0 , 2 9 \%}$ \\
hotel & $79,79 \%$ \\
days_in_waiting_list & $79,75 \%$ \\
previous_bookings_not_canceled & $79,74 \%$ \\
adults & $79,72 \%$ \\
agent & $79,71 \%$ \\
stays_in_week_nights & $79,69 \%$ \\
babies & $79,67 \%$ \\
is_repeated_guest & $79,67 \%$ \\
adr & $79,49 \%$ \\
previous_cancellations & $79,41 \%$ \\
booking_changes & $79,37 \%$ \\
required_car_parking_spaces & $79,19 \%$ \\
lead_time & $78,16 \%$ \\
total_of_special_requests & $\mathbf{7 7 , 7 9 \%}$ \\
\hline
\end{tabular}

Source: (Adi Putro, et al, 2021)

\section{CONCLUSION}

Based on experiments conducted on the hotelbooking-demand dataset using the Deep Neural Network and Logistic Regression algorithm model, several conclusions were obtained. The Encoder-
Decoder layer has an accuracy of $86.57 \%$ by the adamax optimizer which is higher than the Decoderrr-Encoderrrr with an accuracy of $86.56 \%$ by the adadelta optimizer.

After adding the learning rate, the adamax accuracy for the encoder-decoder decreased by $85.58 \%$ for the learning rate of 0.001 , and for the decoderencoder, it also fell to $85.67 \%$ for the learning rate of 0.001 . The results of the top three rankings of each neural network after adding the learning rate show that the smaller the learning rate, the accuracy increases, but we don't know what value is the optimal value for the learning rate.

By using the Logistic Regression algorithm by removing several attributes, the most influential level of accuracy is the country attribute and total_of_special_requests, where the previous accuracy was $79.66 \%$, it increased by $80.29 \%$ when the country attribute was removed because in these attributes there were 177 variations.

\section{REFERENCE}

Adi Putro, N., Septian, R., Widiastuti, Maulidah, M., \& Ferdinandus Pardede, H. (2021). Penelitian Dosen Yayasan.

Afrianto, M. A., \& Wasesa, M. (2020). Booking Prediction Models for Peer-to-peer Accommodation Listings using Logistics Regression, Decision Tree, K-Nearest Neighbor, and Random Forest Classifiers. Journal of Information Systems Engineering and Business Intelligence, 6(2), 123. https://doi.org/10.20473/jisebi.6.2.123-132

Aggarwal, R., \& Ranganathan, P. (2017). Common pitfalls in statistical analysis: Linear regression analysis. Perspectives in Clinical Research, 8(2), 100-102. https://doi.org/10.4103/2229-3485.203040

Al-Smadi, M., Talafha, B., Al-Ayyoub, M., \& Jararweh, Y. (2018). Using long short-term memory deep neural networks for aspect-based-alsmadi2018.pdf. https://doi.org/10.1007/s13042-018-07994

ALOTAIBI, E. (2020). Application of Machine Learning in the Hotel Industry: A Critical Review. Journal of Association of Arab Universities for Tourism and Hospitality, $O(0)$, $0-0$.

https://doi.org/10.21608/jaauth.2020.3878 4.1060

Antonio, N., Almeida, A. de, \& Nunes, L. (2017). Predicting hotel booking cancellations to decrease uncertainty and increase revenue. Tourism \& Management Studies, 13(2), 25-39. https://doi.org/10.18089/tms.2017.13203

Antonio, N., de Almeida, A., \& Nunes, L. (2019). Hotel 
booking demand datasets. ELSEVIER, 22, 4149. https://doi.org/10.1016/j.dib.2018.11.126

Antonio, N., De Almeida, A., \& Nunes, L. (2017). Predicting hotel bookings cancellation with a machine learning classification model. Proceedings - 16th IEEE International Conference on Machine Learning and Applications, ICMLA 2017, 2017-Decem, 10491054.

https://doi.org/10.1109/ICMLA.2017.00-11

Antonio, N., De Almeida, A., \& Nunes, L. (2019). An automated machine learning based decision support system to predict hotel booking cancellations. Data Science Journal, 18(1), 120. https://doi.org/10.5334/dsj-2019-032

Kingma, D. P., \& Ba, J. L. (2015). Adam: A method for stochastic optimization. 3rd International Conference on Learning Representations, ICLR 2015 - Conference Track Proceedings, 1-15.

Kriegeskorte, N., \& Golan, T. (2019). Neural network models and deep learning - a primer for biologists. ArXiv, 1-14.

Lee, M. (2020). a Machine Learning Approach To Improving Forecasting Accuracy of Hotel Demand: a Comparative Analysis of Neural Networks and Traditional Models. Issues In Information Systems, 21(1), 12-21. https://doi.org/10.48009/1_iis_2020_12-21

Leeuwen, R. van. (2018). Cancellation Predictor for Revenue Management applied in the hospitality industry.

Peng, C. Y. J., Lee, K. L., \& Ingersoll, G. M. (2002). An introduction to logistic regression analysis and reporting. Journal of Educational
Research, 96(1), 3-14. https://doi.org/10.1080/002206702095987 86

Putra, J. W. G. (2019). Pengenalan Konsep Pembelajaran Mesin dan Deep Learning. 1235.

Sánchez-Medina, A. J., \& C-Sánchez, E. (2020). Using machine learning and big data for efficient forecasting of hotel booking cancellations. International Journal of Hospitality Management, $\quad 89, \quad 102546$. https://doi.org/10.1016/j.ijhm.2020.102546

Urraca, R., Sanz-Garcia, A., Fernandez-Ceniceros, J., Sodupe-Ortega, E., \& Martinez-de-Pison, F. J. (2015). Improving Hotel Room Demand Forecasting with a Hybrid GA-SVR Methodology Based on Skewed Data Transformation, Feature Selection and Parsimony Tuning. In E. Onieva, I. Santos, E. Osaba, H. Quintián, \& E. Corchado (Eds.), Hybrid Artificial Intelligent Systems (pp. 632643). Cham: Springer International Publishing.

Wang, J., \& Duggasani, A. (2020). Forecasting hotel reservations with long short-term memorybased recurrent neural networks. International Journal of Data Science and Analytics, 9(1), 77-94. https://doi.org/10.1007/s41060-018-01626

World Travel Organization. (2019). International Tourism Highlights : 2019 Edition. Unwto, 124. https://doi.org/10.18111/9789284421152 